\title{
On Evaluative Conceptualizations of Swear Words and Invectives
}

\author{
By Hans-Harry Drößiger*
}

\begin{abstract}
The article deals with evaluative conceptualizations of swear words and invectives in specialized literature on linguistics, although the number of scholarly papers directly thematizing swear words and invectives is rather small. The findings concerning the ways in which swear words and invectives are conceptualized will be presented in the form of theses. For this reason, a number of papers by scholars from Germany, Great Britain, Lithuania, Spain, Sweden, Italy and Ukraine will be quoted as much as is necessary to get an overview of the notion and status of research into swear words and invectives. Furthermore, these observations enable the elicitation of usual evaluative conceptualizations of swear words and invectives. The spectrum of these conceptualizations spreads from absolutely negative to almost positive forms, representing not only the attitudes of scholars, but also those of the language and culture communities, towards the phenomenon. The three aspects of notion, research status, and evaluative conceptualization present a complete picture of how to comprehend swear words and invectives as academic research objects in their own right.
\end{abstract}

Keywords: Evaluative conceptualization, Invective, Linguistics, Swear word, Translation studies

\section{Introduction}

During the pre-research for this topic, it became clear that the lexicalsemantic category swear word and the linguistic-communicative category invective were understood and described differently in several theoretical linguistic papers. This was the starting point for a deeper investigation to seek an answer to the question of how swear words and invectives are comprehended by checking the notions associated with them and looking at the ways in which they were conceptualized. These conceptualizations are meant to generate an evaluation of swear words and invectives by using metaphorical conceptualizations. Therefore, I will call this complex conceptualizing process and its result, in short terms, evaluative conceptualization.

Very often, people say that swear words are dirty words or that they represent a dirty kind of language; they also say that invectives or insults are understood as aggressive or offensive. Characteristics of that kind show 1) how swear words and invectives are conceptualized, not only in common knowledge, but also in some specialized scientific contexts, 2) how this linguistic phenomenon is usually evaluated, and 3) what public and private value it might have.

For the comprehension and evaluation of swear words and invectives as a whole complex phenomenon, certain differences can be stated, which appear as distinct metaphorical conceptualizations. Thus, the aim of this theoretical paper is to compile and to summarize evaluative conceptualizations of swear words and invectives taken from specialized papers written in English and German. As a result, a formula of conceptualizations in the form A IS B will be created to determine what kinds of evaluations of this part of language and language use

\footnotetext{
* University Full Professor \& Senior Researcher, The Kaunas Faculty, Vilnius University, Lithuania.
} 
can nowadays be found in the specialized literature. It is not the aim of this article to present or to describe examples of swear words, not even for illustrative purposes, because from my point of view only large corpora and a fairly well compiled database of swear words should be a basis for empirical work, in order to avoid speculations on the nature of swear words and invectives.

The findings of this theoretical overview will be presented in the form of theses, because this seems to be the most appropriate and compact way of showing the results of the investigation. Additionally, the form of theses can be taken as a basis for further research, both theoretical and practical, into swear words and invectives.

\section{A Brief Notion of the Terms Swear Word and Invective}

Before presenting the status of research into swear words and invectives and their evaluative conceptualizations, these two terms shall be briefly introduced by looking at some sources from several branches of linguistics. To get an understanding of these terms, dictionaries in particular were excluded from this overview, because there is a significant distinction between notions in dictionaries and those in the specialized literature. Only the latter are able to provide definitions within a certain theoretical framework However, the actual situation is not really satisfying, since not all scholars endeavour to set definitions. The impression is that these terms are only used or set to meet other objectives of a presentation or, in the worst case, because the ability is lacking to define what is necessary. Čekuolyte, a Lithuanian researcher in the peculiarities of youth language, pointed out that "researchers struggle to find a valid definition of swearing, ... that sometimes researchers in their studies on swearing do not give any definition of this daily linguistic practice ..." (2014: 5). Nevertheless, some excerpts for defining these two terms might be elicited.

1. The lexical and semantic category swear word can be seen as an instance of semantics and lexicology. Although Lipka does not present a precise definition, he develops a lexical and semantic approach to "stylistically, affectively, or emotionally marked lexemes" based on the concept of connotation, saying "... that connotations can affect either the complete meaning of a lexeme or only specific senses of it ..." (1992: 66). According to Lipka, this "marker" is "taboo", which is merely a categorization of this special vocabulary as a form of or a representation of taboo language. Ljung also focuses on the interplay between denotation and connotation in the case of swear words:

The vocabulary items used in swearing consist of a limited number of taboo words, viz. words whose literal meaning denotes semantic areas that are ... "too private, too vile or too sacred" to be mentioned (2011: viii). 
In contrast to that pure semantic position, the vast majority of scholars attempt to define or to describe swear words by looking at their functions. Such functional approaches are based on the distinction between the denotative and connotative functions of lexical units, which are strictly connected with the foundations of semantics and lexicology. Yet, these so-called connotative functions range from emotional to social aspects of communicative expressions:

... such words [taboo words, swear words - the author] fulfil specific functions in the dialogic interaction ... Emotionally charged language has a phatic or exclamatory rather than a denotative function ... swear words are offensive words, used as an expression of anger, despair, contentment, emotion, etc. ... (Cintas and Remael 2007: 196).

While Cintas and Remael focus only on the emotional aspects, the Lithuanian researcher Čekuolyte states that such words play their part to "index certain social identities" (2014: 4). Her position is shared by the Italian scholars Formentelli and Monti, who present a classification of so-called "slanguage" vocabulary, which includes swear words:

... the investigation of slang vocabulary ... should be extended to dirty words and swearing ... and other similar expressions that fall under the umbrella term slanguage (2014: 171).

The intended classification of slanguage vocabulary in Formentelli and Monti includes "general slang words, specific slang words, dirty slang words and swear words" (2014: 171).

In the specialized German encyclopaedia Metzler Lexikon Sprache ("Metzler's Encyclopaedia of Language"), a quite thorough definition of swear words is given, which includes almost all of the possible aspects of swear words that one might consider investigating.

Schimpfwort (auch Scheltwort, Schmähwort, Tapeinosis < griech $\tau \alpha \pi \varepsilon i ́ v \omega \sigma ı \varsigma$ "Erniedrigung, Demütigung") In Wbb. entsprechend markierte Substantive, mit denen Personen anstatt mit ihrem Namen in abfälliger Weise angeredet bzw. benannt werden ...; > Dysphemismus (Glück 2000: 603).

Swear word (also oath, term of abuse, tapeinosis < Greek $\tau \alpha \pi \varepsilon i ́ v \omega \sigma i \varsigma$ "humiliation, invective"). In dictionaries, accordingly marked nouns to derogatorily address or call people instead of using their names ...; $\ulcorner$ dysphemism (translation: author).

This definition combines a lexical-semantic description with morphological (noun) and functional aspects (to address or call people) to express a speaker's intention to run others down.

To get a more complete picture of swear words, the description presented in Koß (2002) should be considered. He describes the original sources of swear 
words, which gives a more complete picture of swear words and could be called their conceptual background.

Schimpfnamen sind eine Art Kraftausdrücke, die vor allem auf Tierbezeichnungen ... oder auf Bezeichnungen für Menschen, die z. B. gegen Normen verstoßen haben ..., zurückgreifen und jemanden zurechtweisen oder auch bloßstellen sollen (2002: 210).

Swear words are a sort of expletive and especially fall back on names for animals ... or on names for people who, for example, infringe upon social norms ... and they are used to rebuke or expose somebody (translation: author).

2. Although swear words can be taken as a certain part of the vocabulary of a language, they are used to create and to perform the speech act of swearing, sometimes also called invective; in other words, it can be said that swear words only appear in swearing (Havryliv 2009: 16). Scholars frequently refer to a communicative interplay between swear words and swearing. For example, Fritz states:

Die Geschichte von Schimpfwörtern ist gleichzeitig ein Teil der Geschichte der Kommunikationsform des Beschimpfens. Da der Gebrauch von Schimpfwörtern oft auf soziale Konflikte und soziale Stereotype hindeutet, ist auch die Geschichte von Schimpfwörtern in besonders direkter Weise Sozialgeschichte (2006: 113).

The history of swear words is a part of the history of the communication form of swearing, simultaneously. Due to the fact that the use of swear words often aims at social conflicts and social stereotypes, the history of swear words is in a special direct way a social history, too (translation: author).

However, there is not only a historical approach to the complex phenomenon of invectives. Dewaele focuses especially on their functional and discursive potential:

S-T words [i.e., swear words and taboo words - author] are multifunctional, pragmatic units which assume, in addition to the expression of emotional attitudes, various discourse functions. They contribute, for instance, to the coordination of the interlocutors, the organisation of the interaction and the structuring of verbal exchange ... (2004: 205).

According to Hundsnurscher, invectives are wounding speech acts that form a constituting part of the communicative event argument (1997: 372). This means that invectives are not standalone speech acts, but are always included or incorporated into a broader communicative event. 
As pointed out above, swear words are very often used to humiliate other people. A similar definition of invective (swearing), including the use of swear words, is given by Acke, Hornscheidt and Jana:

Unter Beschimpfungen fassen wir alle diejenigen sprachlichen Handlungen, die konventionalisiert verletzend, abwertend oder benachteiligend wirken können und in und durch welche solche Vorstellungen in der sprachlichen Appellation auf Personen reproduziert werden (2011: 9).

Invectives are understood as all those linguistic activities that may have an effect to conventionally humiliate, run down or discriminate somebody. Also, invectives may bring about such a comprehension if they are used to linguistically address people (translation: author).

To sum up, it can be stated that interesting pieces of possible definitions are given; yet, a completely encompassing comprehension of this complex phenomenon seems unavailable at present.

\section{Status of Research}

1. One of the major questions is which branch of linguistics should take swear words and invectives as its research object? Hundsnurscher says:

... daß für die sog. Schimpfwörter spezifische Gebrauchsbedingungen gelten, die in einer pragmatischen Semantik erst noch im einzelnen zu beschreiben wären ... (1997: 373) (highlighting: author).

... that for the use of swear words there are certain conditions, which should be described in detail within the framework of a pragmatic semantics ... (translation: author).

Also, swear words are a research object in the framework of historical linguistics, because they help to explore processes of semantic change and development in the lexis of a language, e.g., in German (Paul 1995: 93-94, Fritz 2005: 39-43, Fritz 2006: 113-114, Schmidt 2008: 219-220). When looking at historical research in the Anglophone world, the situation is not as optimistic because Hughes says that,

... the continuing currency of coarse speech ... has generally been ignored in standard histories of the language, even some of the most recent. ... None of the standard histories of the language has accorded the lower registers or the idioms of obscenity much attention (1998: 2).

The research into swear words and invectives seems to be under-represented in linguistics compared with practical lexicography, as Havryliv puts it: 
Im Gegensatz zur sprachwissenschaftlichen Literatur, die Schimpfwörter zum Forschungsgegenstand hat und nicht sehr umfangreich ist, sind die deutschen Schimpfwörterbücher quantitativ sehr gut vertreten ... (2009: 18).

The specialized literature in linguistics, which makes swear words its research object, is not very extensive in contrast to the numerous German dictionaries of swear words ... (translation: author).

This statement can be taken for granted, because in Bußmann's (2008) specialized dictionary, in the Metzler Lexikon Sprache ("Metzler's Encyclopaedia of Language") and in Fritz (2006), dictionaries are first and foremost listed as sources presenting information about swear words; there are only a few references to them in specialized linguistic papers. However, swear words and invectives are not only a research object in linguistics. Ljung states:

The study of swearing - linguistic and otherwise - was for long a neglected research area. However, the 1960s saw an increased interest in swearing ... and from the beginning of the 1970 s, there has been a steady increase in publications in this area (2011: 3).

This point of view can be accepted; however, the number of publications on swear words and invectives are only negligible - Ljung counts 30 (thirty) papers out of all the scientific output of the last six decades. Karjalainen's statement about the state of research into swear words and invectives is similarly shattering:

Some might feel that swearing and swear words as objects of study do not belong in academia. This attitude is reflected in the fact that relatively little has been said and written about the use of swear words so far, although a number of scholars have dared to venture into these murky waters and contributed to the discussion with research and publications (2002: 4) (highlighting: author).

All in all, Karjalainen names around a dozen authors who have written specialized papers on swear words and invectives - from his date of publishing - within the last 40 years (2002: 8).

A possible reason for this negligible number of linguistic papers is the attitude towards swear words and invectives, which for centuries were seen as something "dirty" or "taboo", often expressed or described with a negative evaluation. Even Karjalainen is not completely free of such a statement, because he describes the research object as "murky waters".

Within the German language area, at least the Brothers Grimm tried to wipe out prejudices against swear words and invectives in their work on the "German Dictionary" (Deutsches Wörterbuch):

Die natur hat dem menschen geboten das geschäft der zeugung so wie der entleerung vor andern zu bergen und die es verrichtenden theile zu hüllen; was diese innere zucht und scheu verletzt, heiszt unzüchtig (obscoenum, 
wahrscheinlich von coenum, also inquinatum, spurcum). was man aber vor den augen der menge meidet, wird man auch ihrem ohr ersparen und nicht aussprechen.

Das verbot ist jedoch kein absolutes, vielmehr da jene verrichtungen selbst natürlich, ja unerläszlich sind (naturalia non sunt turpia), müssen sie nicht nur insgeheim genannt, sondern dürfen unter umständen auch öffentlich ausgesprochen werden (1854: XXXIII-XXXIV).

The nature had commanded men to hide from others the procedures of fathering and of evacuation and to cover all the body parts involved in these procedures. All that infringes the inner disposition and shyness is called indecent (obscoenum, probably from coenum, hence inquinatum, spurcum). Thus, what is hidden from the crowd's view should also be spared from its ears and should not be spoken about out loud.

Yet, this ban is not an absolute one, rather because those procedures are natural and indeed indispensable (naturalia non sunt turpia); they cannot only be said privily, but under certain circumstances they also might be spoken in public (translation: author).

Unlike this natural, partially democratic approach to the phenomenon, the Anglophone tradition is significantly different, because it strives to instil morality into matters of language. An indication of this can be found in the "Preface to a Dictionary of the English Language" by Samuel Johnson (1755):

As politeness increases, some expressions will be considered as too gross and vulgar for the delicate, others as too formal and ceremonious for the gay and airy; new phrases are therefore adopted, which must, for the same reasons, be in time dismissed. Swift, in his petty treatise on the English language, allows that new words must sometimes be introduced, but proposes that none should be suffered to become obsolete. But what makes a word obsolete, more than general agreement to forbear it? And how shall it be continued, when it conveys an offensive idea, or recalled again into the mouths of mankind, when it has once become unfamiliar by disuse, and unpleasing by unfamiliarity? (highlighting: author).

More recent scholarly papers contain statements concerning the background of morality and naturalness related to swear words and invectives, as Fernández puts it:

Many people are shocked by swearing and consider expletives to be offensive, rude, insulting and inappropriate. The reason behind it is that these words are taboo and refer to things that are not to be talked about in public, usually unmentionable bodily functions and sex (2009: 210).

In certain national landscapes of research, the situation is more dramatic. For example, according to Čekuolyte, only five papers on the topic of swear words and invectives have been published in Lithuania in the last 50 years (her 
paper is not included here); four of them focus on Lithuanian dialects only (2014: 4-5).

Changing this unsatisfactory situation should be a future assignment for all researchers with interest in swear words and invectives. A condemnation or disregard of that special part of a language as detrimental, immoral or offensive is no longer an up-to-date attitude. Ljung's statement offers some sort of optimism when he speaks about new ideas in the sciences:

... they take swearing for granted as a linguistic, psychological, social and neurological category in its own right (2011: 4).

Conducting research into swear words and invectives within an interdisciplinary framework will allow the achievement of more, higher quality, more appropriate and easier to prove results on these research objects. Some papers in translation studies also confirm that research into swear words and invectives should not be rejected:

As a linguistic phenomenon, taboo language surely deserves to be studied and analysed (Fernández 2009: 211).

Karjalainen goes one step further:

However, a comprehensive, all-encompassing study of swearing, which takes more than a handful of aspects into account, has yet to see the light of day (2002: 8) (highlighting: author).

This "more than a handful of aspects" constitutes the foundation of a thorough future research programme in linguistics and neighbouring sciences like translation studies to explore swear words and invectives. Specialized journals such as "Swearing", of which only two volumes have been issued (Karjalainen 2002: 9-10), or "Maledicta", which can still be retrieved online ${ }^{1}$, do their part in the research into swear words and invectives.

2. The quality of the theoretical and methodological investigation into swear words and invectives can be stated and evaluated from different perspectives. Hundsnurscher says:

... daß die Linguistik bei der Beschreibung und Analyse des kommunikativen Phänomens Streit noch weitgehend von einer metaphorischen Begrifflichkeit bestimmt ist und daß sie in besonderem Maße auf interdisziplinäre Hilfestellungen seitens der Soziologie und Psychologie angewiesen ist, da es sich hier methodologisch gesehen um eine Schnittstelle handelt, an der die Erklärung linguistischer Phänomene (aggressive Sprechakte und ihre Äußerungsformen) an psychologische und

\footnotetext{
${ }^{1}$ Retrieved from goo.gl/JJRiiy. [Accessed: February 4, 2017]
} 
soziologische Begriffe ... angeschlossen werden muß (1997: 374) (highlighting: author).

... that linguistics was still largely influenced by a metaphorical terminology describing and analysing the communicative event argument and that linguistics had to a certain extent relied on interdisciplinary support from sociology and psychology, which is, from a methodological point of view, an interface with which explanations of linguistic phenomena (aggressive speech acts and how they are used) must be linked (translation: author).

Two aspects are obvious: the "metaphorical terminology" and the interdisciplinarity of research. The former can hardly be avoided because research within the framework of cognitive linguistics shows that metaphorical conceptualizations possess the power to gain knowledge by creating terms for a better understanding of objects. An interdisciplinary approach to swear words and invectives should be on the agenda, because nowadays translation and cultural studies should go hand in hand with linguistics.

\section{Instances of Evaluative Conceptualizations of Swear Words and Invectives}

1. As pointed out above, and found in a common speaker's evaluative knowledge, the complex phenomenon of swear words and invectives was and is metaphorically conceptualized as DIRT, and therefore negatively evaluated. In this regard, the Brothers Grimm noted in the foreword of the first volume of their "German Dictionary" (Deutsches Wörterbuch, DWB) ${ }^{2}$ :

... die natürliche sprache hat in sich die anlage zu beiden, dem feinen wie dem groben: aus der edlen sprache ist der grobe, aus der groben der edle bestandtheil entfernt; das grobe, derbe wird leicht unrein und schmutzig (sordidum, turpe), das feine geziert und zimpferlich (ornatum, molle), oder auch schlüpfrig (lubricum) erscheinen (1854: XXXIII).

... natural language has in itself the potential to be both the fine and coarse: from the noble language were the coarse and from the coarse language the noble parts removed; the coarse and the crude might easily appear as impure and dirty (sordidum, turpe), the fine as affected and squeamish (ornatum, molle), or as salacious (lubricum) (translation: author).

However, this statement has to be seen as a rejection of the standpoint of Adelung, who published his German dictionary (first edition 1774-1786) approximately 80 years before the Brothers Grimm. Adelung had intended to remove, or to at least ignore, all of these "dirty" words in the vocabulary. Therefore, the Brothers' Grimm reply was:

\footnotetext{
${ }^{2}$ Retrieved from goo.gl/qRxrCX. [Accessed: August 2, 2016]
} 
die sprache überhaupt in eine erhabne, edle, trauliche, niedrige und pöbelhafte zu unterscheiden taugt nicht, und ADELUNG hat damit vielen wörtern falsche gewichte angehängt. wie oft verleugnet er den beruf eines sprachforschers mit der wiederholten äuszerung: "diese wörter sind so niedrig, dasz sie kaum angeführt zu werden verdienen" und wie mengt er alle diese arten untereinander (1854: XXXIII).

To divide a language into sublime, noble, intimate, mean and vulgar categories does not make any sense, and ADELUNG had attached wrong labels to too many words. He frequently denied the profession of a language researcher by saying repeatedly: "these words are so mean, thus, they have almost no value to be listed"; he also merges all these types together (translation: author).

Yet, it should be noted that the "dirt" really appears in the speakers' evaluative conceptualizations. For centuries, DIRT has been, and still is, the dominant evaluative concept for swear words and invectives. Nunberg (1992) entitled his whole article "Dirty Words", in which he presents an overview of how these "dirty words" as a part of a "dirty language" were understood and evaluated in the Victorian era of Great Britain. Interestingly, Nunberg states that this "dirt" in a language might cause "diseases" in a language.

The evaluation of swear words and invectives as DIRT, using procedures of metaphorical conceptualization (in short terms: evaluative conceptualization), is not yet completely extinct. It seems to be taken for granted that, in a scientific sense, this evaluative conceptualization has been transferred from a linguistic phenomenon to the speakers' mental disposition. This has been confirmed by a number of recent publications; e.g., Formentelli and Monti classify "dirty words and swearing" as a certain part of the vocabulary of slang (2014: 171).

However, Karjalainen (2002) contradicts the conceptualization of swear words and invectives as DIRT as it still exists in many publications and in the common awareness of language. He follows the Brothers' Grimm attitude to language, as outlined above, saying that,

... the "dirtiness" associated with swear words and foul language in general resides in our minds - not in the language or in the words themselves. Thus ... the study of swear words and dirty language is as motivated as any other linguistic study (5).

2. The conceptualization that SWEAR WORDS AND INVECTIVES ARE DIRT was seriously taken for granted in Great Britain during the $19^{\text {th }}$ century, as Nunberg (1992) has pointed out. The reasons for this fundamental evaluative conceptualization were the efforts to cultivate the language in that era by looking at certain sources, according to which the whole language was characterized as "degenerate, pest, epidemics, infectious disease, disease". In other words, SWEAR WORDS AND INVECTIVES ARE DISEASE-CAUSING AGENTS in a language that suffers from slang and other negative variations. Therefore, 
it may be stated that LANGUAGE VARIATIONS ARE DISEASES, which have an enormous impact on society and thinking. Yet, this may lead to some more metaphorical conceptualizations concerning socially or stylistically determined language variations in which swear words and invectives are in use. Nunberg states:

Slang is different from cant in two crucial ways. First of all, it is illegitimate language, or "unauthorized" as some writers put it; language that appeared to have broken loose from its original social provenance and come to rest in some alien variety or register (highlighting: author).

These additional metaphorical conceptualizations, related to the general comprehension of a language, would be NON-STANDARD LANGUAGE IS ILLEGITIMATE and NON-STANDARD LANGUAGE IS ALIEN. These evaluative conceptualizations are grounded not only in a negative moral evaluation, but also in a strict rejection of the concerned vocabulary and its use in speech. Thereby, until the present day, this vocabulary and its use have been stigmatized by the use of certain markers in modern dictionaries ${ }^{3}$. Yet, the Brothers' Grimm basic idea about the one and only serious intention for the work of linguists and lexicographers mentioned in the preface of their "German Dictionary" (Deutsches Wörterbuch) is repeatedly overlooked:

Das wörterbuch ist kein sittenbuch, sondern ein wissenschaftliches, allen zwecken gerechtes unternehmen (1854: XXXV).

The dictionary is not a book of morals but a scientific one, an enterprise meeting all purposes. (translation: author).

However, more intelligible is the fact that, caused by the metaphorical conceptualizations of swear words and invectives as DIRT, DISEASE-CAUSING AGENTS, DISEASE, ILLEGITIMATE and ALIEN, the potential to be conceptualized as a THREAT is present. Indeed, swear words and invectives might nowadays be theoretically categorized or classified as such.

3. Yet, being comprehended and thus conceptualized as a THREAT seems to be too weak for a number of language researchers, because swear words and invectives are labelled with the concept of AGGRESSIVENESS. However, it goes further than SWEAR WORDS AND INVECTIVES ARE A THREAT or SWEAR WORDS AND INVECTIVES MEAN AGGRESSIVENESS. Čekuolyte says that another idea, FEAR, seems to be used for an evaluative conceptualization of swear words and invectives: "People also swear to gain power and to scare others" (2014: 4).

From my point of view, this fear is partially expressed in overly exaggerated terms by some scholars who have entitled their works and papers using the concept of AGGRESSIVENESS. The German scholar Kiener (1983)

3 The marker "obscene", used in dictionaries to label certain words or phrases, comes from Latin obscenus/obscoenus and simply means "dirty". 
entitled his book Das Wort als Waffe ("The Word as a Weapon") ${ }^{4}$, and Havryliv (2009) gave her book the title Verbale Aggression ("Verbal Aggression"), using the concepts of AGGRESSIVENESS and FEAR in a more common sense to characterize not only swear words and invectives as aggressive and scary, but also large fields of language use and partially even a whole language as fear-inducing.

Anderson and Trudgill give a broader statement about language in general: "Language contains explosive items which should be handled with care" (1990: 4). This evaluative conceptualization as EXPLOSIVE can be understood as a superior conceptualization, under which the following ones appear as subconceptualizations, because Anderson and Trudgill do not explicitly speak about swear words and invectives.

Although there might be a connection to the aggressive potential of swear words and invectives, they are in the first instance metaphorically conceptualized as a WEAPON, which can be meant humorously or even ironically.

Whether words really have more power than bullets remains to be seen, but it is true that some swear words and taboo words ( $\mathrm{S}$-T words) are the verbal equivalent to nitroglycerine. This might be the reason why some native speakers (NSs) avoid using them in public and why nonnative speakers (NNSs) seem generally reluctant to use them. Indeed, inappropriate use of swear words or taboo words might have devastating social consequences (Dewaele 2004: 204) (highlighting: author).

Thus, it is not only about the potential of swear words and invectives to be used as a "weapon", but also about the effects that their use can have: the devastation of social conditions. This is a form of expressing the more common concept of CAUSE AND EFFECT. Dewaele (2004) intensifies the metaphorical conceptualization as a WEAPON by summing up:

Language users seem to avoid use of linguistic "nuclear" devices if they are unsure about the yield (emotional force) and potential illocutionary or perlocutionary effects (220) (highlighting: author).

According to the concept of CAUSE AND EFFECT, Hundsnurscher brings into play the effects intended by a speaker/writer:

Der Variantenreichtum der Äußerungsformen für Beschimpfungen ist ... bedingt durch das Bestreben nach Treffsicherheit: Die verletzbaren Punkte des Gegenübers sind oft sehr verdeckt, und es bedarf häufig genauer Kenntnis der Person, um den Treffer da setzen zu können, wo er den größten Schmerz bereitet (1997: 373).

\footnotetext{
4 Yet, this kind of conceptualization is not really new, as a Google search has shown [last access: 2 August, 2016], because with such an utterance it has been and still is possible to repeatedly refer to the use and misuse of language in the areas of politics, ideology and religion, especially in the mass media and in religious interpretation.
} 
The comprehensiveness of variations in utterances to perform invectives is ... determined by the endeavour to achieve marksmanship: the opponent's vulnerable points are sometimes hard to detect, and it often requires accurate knowledge of the person to hit them where it will cause the greatest pain (translation: author).

Bearing in mind that swear words and invectives can be used as a "weapon" to cause pain, anger, wrath or to devastate social relations, even if they are used ironically, there might be another side to them. Hughes characterizes swear words and invectives by looking at their special effects in human speech. In his words, they can be "a crudely unpredictable rhetorical firework" (1998: 86). An evaluative conceptualization, that SWEAR WORDS AND INVECTIVES ARE FIREWORKS, can be assumed. Speaking of a "rhetorical firework", there is a way to interpret the use of swear words and invectives as linguistic means to create, organize, progress and push forward certain forms of conversation, e.g., an argument.

4. In the meantime, it seems that the common evaluation of swear words and invectives is not only exclusively oriented to rejection, disapproval, contempt or dangerousness. In more recent papers in linguistics and translation studies, a conceptualization that could surely be positively interpreted is: SWEAR WORDS AND INVECTIVES ARE LIKE SPICE.

On the other hand, not each and every swear word needs to be translated in order to convey characters' register and/or personalities: peppering their speech with the occasional well-placed expletive will often do the trick (Cintas and Remael 2007: 200) (highlighting: author).

If we take SPICE as a sub-concept of the concept FOOD, another evaluative conceptualization comes into play. Anderson and Trudgill call swear words and invectives a "forbidden fruit", talking about the influences of mass media, especially TV, on younger audiences. They write:

We find it hard to believe that one or two swearers out of the hundreds of people appearing on TV can seduce a child into using swear words, unless the child really wants to pick the forbidden fruit, taste it and test it (1990: 49) (highlighting: author).

Thus, the evaluative conceptualization that SWEAR WORDS AND INVECTIVES ARE FORBIDDEN FRUITS can be set. This leads to an interpretation of a more or less ambivalent conceptualization, because a positive as well as negative interpretation of swear words and invectives is possible. The latter undoubtedly refers to a religious background according to Genesis 3, 2-3. Therefore, the concept of FORBIDDEN FRUIT can be seen as a part of Christian culture and as a constituent of the Western cultural background. However, the ambivalence of this evaluative conceptualization is due to the component FRUIT: fruit is food, it is tasty and sweet, and it satisfies not only hunger, but also the desire for enjoyment. Additionally, the last remark in the quote from 
Anderson and Trudgill refers to one quality of swear words and invectives already mentioned above: to "test" them means to try out how they might work in a conversation and what functions they can fulfil in human speech. In the process of a child's language acquisition, as Anderson and Trudgill have clearly pointed out (1990: 49), swear words and invectives should not be avoided; instead, children must learn to handle them. In this way, swear words and invectives deserve to be positively evaluated.

5. The trend in positively evaluating swear words and invectives can be seen in their relationship with the more global concept of HUMOUR, which swear words and invectives play their part in linguistically expressing. Fernández describes humorous situations in animated films in which main characters use swear words, curses and expletives:

The humour lies in using the naive, child-like simplicity of the animation to offset adult themes in the storylines, which are in turn propelled by a manic and unrelenting catalogue of obscenities (2009: 214).

Swear words and invectives might be seen as a linguistic means of humour, and it would be possible to conceptualize them as such; on the other hand, there is more to humour than its linguistic determinants. Cultural, societal and behavioural aspects, as well as characteristics of communicative situations, events, speech acts and the media, have to be considered to comprehend humour or humorous situations. The actual role of swear words and invectives in producing and understanding humour remains a task for future research.

\section{Summary and Conclusions}

In the present day, the notion of swear words and invectives consists not only of definitions or definition-like descriptions, but also of conceptualizations which help to comprehend these phenomena. These conceptualizations take the form of metaphorical conceptualizations and present an evaluation of swear words and invectives. The evaluative conceptualizations can be seen on a scale from negative to ambivalent to positive (Figure 1).

Figure 1. Evaluative Conceptualizations of Swear Words/Invectives 
SWEAR WORDS / INVECTIVES

ARE

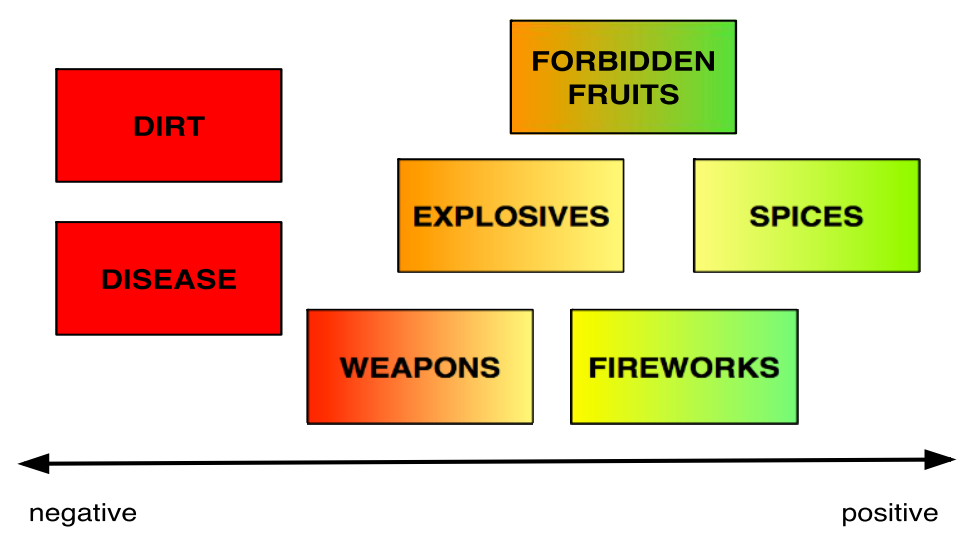

Source: Author.

On the one hand, these different evaluative conceptualizations depict scholars', researchers', and lexicographers' subjective attitudes towards this research object. On the other hand, these evaluative conceptualizations allow the creation of a complete theoretical picture of swear words and invectives, because they not only define terms, but also state what value these highly sensitive parts of the vocabulary of a language and culture community might have. Swear words and invectives allow the expression of insults, contempt, discrimination and disparagement (to name but a few of their functions and purposes); however, the attitude of language and culture communities towards these functions is changing over time. Therefore, an investigation into swear words and invectives should go beyond the narrow, restricted, and isolated approaches of linguistics. Nowadays, the door to interdisciplinary research into swear words and invectives is open, because the appearance of swear words and invectives itself is multidimensional. The use of swear words and invectives is, in the present day, no longer restricted to slang, colloquial language, dialects or linguistic communication in private; nor is there an absolute censorship because swear words and invectives can be widely observed in public, for example, in politicians' speeches, TV shows, Internet forums etc. Their appearance in public in particular indicates that the status of swear words and invectives within a language and culture community has changed since, for example, Johnson's dictionary was published, notably in English-speaking parts of the world. These changes have caused an increasing interest in swear words and invectives as serious research objects in their own right by all those sciences that might have an interest in language: linguistics, translation studies, sociology, cultural studies, media studies, psychology, educational sciences and journalism.

However, a reliable notion of swear words and invectives that considers all linguistic and non-linguistic aspects should be on the agenda. The reason for this lies in the terminological confusion, merging and mixing of designations, which can now be observed. Scholars call the object "swear word" and list exclamations; others call the object "taboo words" and sort curses into it. Clarity and definiteness of all terms related to swearing and cursing is necessary. A first approach to this definiteness would be to call all those nouns 
swear words whose function is to directly address people in a conversation by intentionally abusing them or to refer to people who are not directly involved in a conversation by also intentionally abusing them.

The given overview of evaluative conceptualizations can be taken as a starting point to work out an appropriate and complex notion of swear words and invectives as sub-concepts of more common, more complex, and more sophisticated concepts in a language and culture community, like HUMOUR, EMOTIONS OR POLITENESS; but also of basic logical concepts, like CAUSE AND EFFECT and POLARITY. 


\section{References}

Acke H, Hornscheidt AL, Jana I (2011) Einleitung (Introduction). In AL Hornscheidt, I Jana, H Acke (Eds.), Schimpfwörter - Beschimpfungen - Pejorisierungen. Wie in Sprache Macht und Identitäten verhandelt werden (Swear words - Insults Pejorations. How power and identities are negotiated in language)., Frankfurt/ Main: Brandes \& Apsel, pp: 7-14.

Anderson L, Trudgill P (1990) Bad Language. Oxford: Basil Blackwell.

Bußmann H (2008) Lexikon der Sprachwissenschaft. 4., durchgesehene und bibliographisch ergänzte Auflage (Encyclopedia of Linguistics. $4^{\text {th }}$, revised and bibliographically extended edition). Stuttgart: Kröner.

Čekuolyte A (2014) "He blet nachui was in a shop": Swearing Practices and Attributes to Swearing among Vilnius Adolescents. Taikomoji kalbotyra, 6. Retrieved from goo.gl/EDKLCE [Accessed: August 7, 2017]

Dewaele J-M (2004) The Emotional Force of Swearwords and Taboo Words in the Speech of Multilinguals. Journal of Multilingual and Multicultural Development 25(2/3): 204-222.

Díaz Cintas J, Remael A (2007) Audiovisual Translation: Subtitling. London, New York: Routledge.

Fernández MJF (2009) The Translation of Swearing in the Dubbing of the Film South Park into Spanish. In J Díaz Cintas (Eds.), New Trends in Audiovisual Translation. Bristol, Buffalo, Toronto: Multilingual Matters, pp: 210-225.

Formentelli M, Monti S (2014) Translating Slanguage in British and American Films: A Corpus-based Analysis. In M Pavesi, M Formentelli, E Ghia (Eds.), The Languages of Dubbing. Mainstream Audiovisual Translation in Italy. Berlin: Lang, pp: 169-195.

Fritz G (2005) Einführung in die historische Semantik (Introduction into Historical Semantics). Tübingen: Niemeyer.

Fritz G (2006) Historische Semantik. 2., aktualisierte Auflage (Historical Semantics. $2^{\text {nd }}$, revised edition). Stuttgart, Weimar: Metzler.

Glück H (Ed.) (2000) Metzler Lexikon Sprache. 2., überarbeitete und erweiterte Auflage (Metzler's Encyclopaedia of Language. $2^{\text {nd }}$, revised and extended edition). Stuttgart, Weimar: Metzler.

Grimm J, Grimm W (1998-2004) Deutsches Wörterbuch (German Dictionary). Retrieved from: http://www.dwb.uni-trier.de/ [Original: 1852-1960] [= DWB].

Havryliv O (2009) Verbale Aggression. Formen und Funktionen am Beispiel des Wienerischen (Verbal Aggression. Its Forms and Functions Exemplified by the Viennese City Dialect). Frankfurt/Main: Lang.

Hughes G (1998) Swearing. A Social History of Foul Language, Oaths and Profanity in English. London: Penguin Books.

Hundsnurscher F (1997) Streitspezifische Sprechakte: Vorwerfen, Insistieren, Beschimpfen (Specialized Speech Acts of Argument: Accusing, Insisting, Swearing). In G Preyer, MUlkan, A Ulfig (Eds.) Intention - Bedeutung - Kommunikation. Kognitive und handlungstheoretische Grundlagen der Sprechakttheorie (Intention Meaning - Communication. Foundations of Speech Act Theory from Points of View of Cognitive and Action Theory). Opladen: Westdeutscher Verlag, pp: 363-375.

Johnson S (1755) Preface to a Dictionary of the English Language. Retrieved from goo.gl/mZJRWx. [Accessed: October 28, 2016]

Karjalainen M (2002) Where have all the swearwords gone? An analysis of the loss of swearwords in two Swedish translations of J.D. Salinger's Catcher in the Rye. 
Pro Gradu thesis. University of Helsinki. Retrieved from: goo.gl/zaYM7L. [Accessed: July 27, 2016].

Kiener F (1983) Das Wort als Waffe. Zur Psychologie der verbalen Aggression (The Word as a Weapon. On Psychology of Verbal Aggression). Göttingen: Vandenhoeck \& Ruprecht.

Koß G (2002) Namenforschung. Eine Einführung in die Onomastik. 3., aktualisierte Auflage (Research into Proper Names. An Introduction to Onomastics. $3^{\text {rd }}$, revised edition). Tübingen: Niemeyer.

Lipka L (1992) An Outline of English Lexicology. Lexical Structure, Word Semantics, and Word-Formation. Second Edition. Tübingen: Niemeyer.

Ljung M (2011) Swearing. A Cross-Cultural Linguistic Study. New York, Houndmills: Palgrave Macmillan.

Nunberg G (1992) Dirty Words. Retrieved from: goo.gl/t7prfz. [Accessed: July 27, 2016]

Paul H (1995) Prinzipien der Sprachgeschichte. 10., unveränderte Auflage (Principles of Language History. $10^{\text {th }}$, unchanged edition). Tübingen: Niemeyer.

Schmidt W (2008) Deutsche Sprachkunde. Ein Handbuch für Lehrer und Studierende mit einer Finfiihrung in die Prohleme des snrachkundlichen I/nterrichts. 8. Auflage 